IZA DP No. 6985

The Effect of Overskilling Dynamics on Wages

Kostas Mavromaras

Stéphane Mahuteau

Peter Sloane

Zhang Wei

November 2012 


\title{
The Effect of Overskilling Dynamics on Wages
}

\author{
Kostas Mavromaras \\ NILS, Flinders University \\ and IZA \\ Stéphane Mahuteau \\ NILS, Flinders University \\ and IZA \\ Peter Sloane \\ NILS, Flinders University, \\ Swansea University and IZA \\ Zhang Wei \\ NILS, Flinders University
}

\section{Discussion Paper No. 6985 \\ November 2012}

\author{
IZA \\ P.O. Box 7240 \\ 53072 Bonn \\ Germany \\ Phone: +49-228-3894-0 \\ Fax: +49-228-3894-180 \\ E-mail: iza@iza.org
}

\begin{abstract}
Any opinions expressed here are those of the author(s) and not those of IZA. Research published in this series may include views on policy, but the institute itself takes no institutional policy positions. The IZA research network is committed to the IZA Guiding Principles of Research Integrity.

The Institute for the Study of Labor (IZA) in Bonn is a local and virtual international research center and a place of communication between science, politics and business. IZA is an independent nonprofit organization supported by Deutsche Post Foundation. The center is associated with the University of Bonn and offers a stimulating research environment through its international network, workshops and conferences, data service, project support, research visits and doctoral program. IZA engages in (i) original and internationally competitive research in all fields of labor economics, (ii) development of policy concepts, and (iii) dissemination of research results and concepts to the interested public.
\end{abstract}

IZA Discussion Papers often represent preliminary work and are circulated to encourage discussion. Citation of such a paper should account for its provisional character. A revised version may be available directly from the author. 
IZA Discussion Paper No. 6985

November 2012

\section{ABSTRACT}

\section{The Effect of Overskilling Dynamics on Wages}

We use a random effects dynamic probit model to estimate the effect of overskilling dynamics on wages. We find that overskilling mismatch is common and more likely among those who have been overskilled in the past. It is also highly persistent, in a manner that is inversely related to educational level. Yet, the wages of university graduates are reduced more by past overskilling, than for any other education level. A possible reason for this wage effect is that graduates tend to be in better-paid jobs and therefore there is more at stake for them if they get it wrong.

JEL Classification: J24, J31

Keywords: mismatch, overskilling, wages, panel dynamic estimation

Corresponding author:

Kostas Mavromaras

National Institute of Labour Studies (NILS)

Flinders University

Adelaide, SA 5001

Australia

E-mail:k.mavromaras@flinders.edu.au

\footnotetext{
* The paper is drawn from a report undertaken for the National Centre for Vocational Education Research (NCVER) (Mavromaras et al. 2012a). The data used is the confidentialised unit record file from the HILDA survey. The HILDA survey project was initiated and is funded by the Australian Government Department of Families, Housing, Community Services and Indigenous Affairs and is managed by the Melbourne Institute. Financial support by the NCVER is gratefully acknowledged.
} 


\section{Introduction}

Mismatch in the labour market as a form of human capital under-utilisation is attracting increased attention by academic researchers and policy practitioners alike. Skills under-utilisation in the workplace is defined as the situation where workers may have skills and abilities that they do not use in their job and which has been called overskilling. There are few analyses of the over time persistence of overskilling, and none of them has been able to examine the longer term nature of persistence, largely due to data limitations. This study utilises the first nine waves of the Household, Income and Labour Dynamics in Australia (HILDA) survey, which enables us to estimate the lagged effect of persistence. To the degree that overskilling represents a genuine labour market imbalance and is also self persistent, it can have a dampening effect on the growth potential of the economy.

Existing research on labour market mismatch caused by overskilling has examined the extent of overskilling in Australia, its impact on wage levels, on job mobility, and on job satisfaction, and in a more limited way its persistence over time, using the HILDA survey, which is the only currently running panel household survey directly reporting overskilling. Several results have been established. ${ }^{1}$ First, overskilling has a negative wage effect. The overskilled are observed to have lower wages than their wellmatched comparators. This has been called the 'overskilling wage penalty' and has been measured as a percentage wage difference between the wages of the overskilled and the well-matched. The overskilling wage penalties differ by level of education. The highest wage penalty is suffered by university graduates who are overskilled. The second highest wage penalty is suffered by overskilled workers who are without post-

\footnotetext{
${ }^{1}$ See Mavromaras et al. 2009a, 2009b, 2010a, 2010b, 2012b, 2012c.
} 
school qualifications and the lowest, by workers with vocational education and training (VET) qualifications. In some instances empirical research has not managed to establish a statistically significant wage penalty for overskilled VET graduates.

Second, there is limited evidence suggesting that overskilling is a self-persistent labour market state. The meaning of self-persistent is that an overskilled person today is more likely to be overskilled tomorrow, because they are overskilled today. That is, being overskilled is a self-perpetuating state, over and above all the personal and labour market reasons that make someone overskilled in the first place. Selfpersistence in general is a common problem with adverse labour market outcomes and is typically associated with some form of scarring, which works against the longerterm prospects of workers. The investigation of self-persistence requires longitudinal data, which are rare for any form of labour market mismatch. Mavromaras et al. (2009b) provided limited evidence on the self-persistence of overskilling in the Australian labour market. They found that the education pattern followed by the strength of overskilling self-persistence is similar to that followed by the wage penalties. University graduates suffer the highest wage penalties and show the highest persistence, workers without post-school qualifications are next, and VET graduates suffer the least. However, their analysis was limited by the use of too short a longitudinal data set.

While previous research provides evidence on the presence of overskilling self persistence and of overskilling wage penalties, their crucial interaction has not been examined. Namely, we do not know how much the negative wage penalties caused by overskilling may themselves be persistent. This question is the focus of this paper. Underlying the question of self persistent wage penalties is the deeper economic distinction of whether overskilling mismatch is either a scarring labour market 
phenomenon, that is, a phenomenon which we would expect to cause long-lasting damage to those workers who end up being overskilled in the long run, or an adjustment process, in which case we would expect the labour market negative outcomes associated with overskilling to be transient and eliminated by the market sorting with time. To establish this we need to examine how both the self-persistence of overskilling mismatch and the wage penalties that are caused by self-persistent overskilling mismatch may work in tandem to create either a disadvantage that will not be time persistent, or a disadvantage that will be time persistent. It is in this latter case that the paper identifies the potential for an extreme form of scarring, where selfpersistence and wage penalties may reinforce each other.

This paper estimates a model of overskilling mismatch which allows for the presence of self-persistence. It then examines the degree of damage that self-persistence generates in terms of lost wages for the overskilled workers. The paper is structured as follows: The second section presents the data. It describes overskilling mismatch and other pertinent attributes of the data. Section 3 presents the estimation methodology. Section 4 presents and discusses the results. Section 5 concludes. Appendix I contains definition of variables and descriptive statistics. An extended Appendix II, which is available upon request, contains the complete estimation results. 


\section{Data and descriptive statistics}

The paper uses waves 1-9 (2001-2009) of the HILDA survey. ${ }^{2}$ We use an unbalanced panel of all working-age people (16-64 years males and 16-59 years females) in paid employment who provided complete information on the variables of interest. Selfemployed and full-time students are excluded. The sample size we retain is approximately 5,300 observations per wave.

Following the findings in the literature that overskilling differs drastically by level of education, we split the data into the following five educational categories based on the highest education level achieved at the time of interview: University degrees (including bachelor degrees, graduate certificates, graduate diplomas, and higher degrees); Advanced diplomas and diplomas (one to two year vocational training resembling university education); Certificates (the traditional vocational Australian qualifications of 6-12 months); Only completed school (Year 12) and Did not complete school (Below Year 12). ${ }^{3}$

The overskilling variable used in this paper is derived from the self-completed questionnaire of the HILDA survey. Interviewees are asked to respond on a sevenpoint scale to the statement 'I use many of my skills and abilities in my current job', with a response of 1 corresponding to strongly disagree, up to 7 strongly agree. Individuals selecting $1,2,3$, or 4 on the scale are classified as overskilled and those selecting 5 or higher are classified as well-matched. Experimentation and sensitivity

\footnotetext{
${ }^{2}$ See Watson and Wooden (2004) for a detailed description of the HILDA data.

${ }^{3}$ There is also a VET category (Certificates I and II) which is typically subsumed in the category 'Did not complete school', depending on their highest year of schooling completed.
} 
analyses show that the results are not affected by the specific cut off point used. ${ }^{4}$ The way the overskilling question is asked in the HILDA survey does not allow the researcher to examine the phenomenon of under-skilling and so we do not address this further. Thus, all comparisons and results in the following analysis look just at the under-utilisation side of potential skills mismatch.

Table 1 The distribution of overskilled employees by education pathway

\begin{tabular}{lccccc}
\hline & \multicolumn{2}{c}{ Well-matched } & \multicolumn{2}{c}{ Overskilled } & Total \\
& Cases & Per cent & Cases & Per cent & Cases \\
\hline University Degrees & 11,669 & 85 & 2,094 & 15 & 13,763 \\
Diplomas & 3,708 & 80 & 924 & 20 & 4,632 \\
Certificates III/IV & 8,385 & 80 & 2,049 & 20 & 10,434 \\
Only completed school & 5,442 & 71 & 2,230 & 29 & 7,672 \\
Did not complete school & 8,010 & 70 & 3,426 & 30 & 11,436 \\
Total & 37,214 & 78 & 10,723 & 22 & 47,937 \\
\hline Notes: The sample is person-years of working age paid employees from HILDA $2001-2009$. &
\end{tabular}

Table 1 reports the incidence of overskilling by educational level. The data show that the incidence of overskilling varies significantly across educational category.

The objective of the paper is to estimate the effect of past overskilling on present overskilling through the use of lags in the dependent variable. The presentation of estimation results of this type often lacks in intuitive appeal as the reference categories of the lags can be too complex to visualise. To help with intuition we look at the patterns of overskilling over time and describe over-time persistence for a

\footnotetext{
${ }^{4}$ The application of different cut-off points makes no qualitative difference, with lower cutoff points reducing the number of those categorised as overskilled but obviously picking from the sample the more overskilled people, thus increasing the size of the effects of overskilling, | but applying it to a smaller part of the sample.
} 
number of scenarios of past individual experience. Table 2 describes the patterns of overskilling over time by educational level. It takes the present overskilling state (row below educational levels) and then provides the numbers found for eight distinct scenarios, beginning with ' 000 ' for 'never overskilled in the past three years', to ' 111 ' for 'overskilled in all of the last three years'. The largest category is those who are presently well-matched and were never overskilled in the last three years (for example, for university graduates 4503 person-years). Note that there is a sizeable minority who were continuously overskilled for all years (218 for university graduates and 1,057 for the whole sample).

Table 2 Patterns of overskilling over time

\begin{tabular}{|c|c|c|c|c|c|c|c|c|c|c|}
\hline \multirow{3}{*}{$\begin{array}{l}\text { Overskilling } \\
\text { at } \\
(\mathrm{t}-1, \mathrm{t}-2, \mathrm{t}-3)\end{array}$} & \multicolumn{10}{|c|}{ Overskilling status at time $t$} \\
\hline & \multicolumn{2}{|c|}{ University degrees } & \multicolumn{2}{|c|}{ Diplomas } & \multicolumn{2}{|c|}{ Certificates III/IV } & \multicolumn{2}{|c|}{$\begin{array}{l}\text { Only Completed } \\
\text { school }\end{array}$} & \multicolumn{2}{|c|}{$\begin{array}{l}\text { Did not complete } \\
\text { school }\end{array}$} \\
\hline & $\begin{array}{c}\text { Well- } \\
\text { Matched }\end{array}$ & $\begin{array}{c}\text { Over } \\
\text { skilled }\end{array}$ & $\begin{array}{c}\text { Well- } \\
\text { Matched }\end{array}$ & $\begin{array}{l}\text { Over } \\
\text { skilled }\end{array}$ & $\begin{array}{c}\text { Well- } \\
\text { Matched }\end{array}$ & $\begin{array}{c}\text { Over } \\
\text { skilled }\end{array}$ & $\begin{array}{c}\text { Well- } \\
\text { Matched }\end{array}$ & $\begin{array}{c}\text { Over } \\
\text { skilled }\end{array}$ & $\begin{array}{c}\text { Well- } \\
\text { Matched }\end{array}$ & $\begin{array}{l}\text { Over } \\
\text { skilled }\end{array}$ \\
\hline$(1,0,0)$ & 223 & 94 & 80 & 38 & 231 & 101 & 137 & 72 & 225 & 114 \\
\hline$(0,1,0)$ & 252 & 49 & 102 & 22 & 244 & 77 & 141 & 64 & 234 & 104 \\
\hline$(0,0,1)$ & 355 & 66 & 122 & 28 & 275 & 64 & 212 & 61 & 272 & 102 \\
\hline$(1,1,0)$ & 88 & 83 & 23 & 42 & 84 & 89 & 69 & 61 & 96 & 136 \\
\hline$(1,1,1)$ & 130 & 218 & 52 & 105 & 86 & 143 & 98 & 211 & 133 & 380 \\
\hline
\end{tabular}

Note: Since three lags of overskilling are introduced, the sample here only contains working-age paid employees from HILDA 20042009. For ease of interpreting an element in a bracket, 1 refers to a period of overskilling and 0 to a period where the employee is wellmatched.

We know that current overskilling is associated with lower wages. Table 3 below shows how present wages are associated with past overskilling patterns by educational level. The more spells there are of overskilling, the lower is the wage. This is particularly so for university graduates, to a degree also for diploma graduates 
and Year 12 graduates. There is no association between wages and overskilling for Certificate III/IV holders and workers with Year 11 or less.

It is clear that more overskilling is associated to higher wage losses for better paid workers (university graduates and diploma graduates). The same applies to Year 12 school graduates, with little evidence of wage losses being influenced in any systematic way by the historic pattern of overskilling for Certificate III/IV graduates and Year 11 or less workers.

Table 3 Hourly wages by overskilling pattern and educational level

\begin{tabular}{|c|c|c|c|c|c|c|c|c|c|c|}
\hline \multirow[t]{2}{*}{$\begin{array}{c}\text { Overskilling } \\
\text { at } \\
(\mathrm{t}-1, \mathrm{t}-2, \mathrm{t}-3) \\
\end{array}$} & \multicolumn{2}{|c|}{$\begin{array}{c}\text { University } \\
\text { degrees }\end{array}$} & \multicolumn{2}{|c|}{ Diplomas } & \multicolumn{2}{|c|}{$\begin{array}{c}\text { Certificates } \\
\text { III/IV } \\
\end{array}$} & \multicolumn{2}{|c|}{$\begin{array}{c}\text { Only Completed } \\
\text { school }\end{array}$} & \multicolumn{2}{|c|}{$\begin{array}{c}\text { Did not complete } \\
\text { school }\end{array}$} \\
\hline & $\begin{array}{c}\text { Well- } \\
\text { Matched }\end{array}$ & $\begin{array}{c}\text { Over } \\
\text { skilled }\end{array}$ & $\begin{array}{c}\text { Well- } \\
\text { Matched }\end{array}$ & $\begin{array}{c}\text { Over } \\
\text { skilled }\end{array}$ & $\begin{array}{c}\text { Well- } \\
\text { Matched }\end{array}$ & $\begin{array}{c}\text { Over } \\
\text { skilled }\end{array}$ & $\begin{array}{c}\text { Well- } \\
\text { Matched }\end{array}$ & $\begin{array}{c}\text { Over } \\
\text { skilled }\end{array}$ & $\begin{array}{c}\text { Well- } \\
\text { Matched }\end{array}$ & $\begin{array}{c}\text { Over } \\
\text { skilled }\end{array}$ \\
\hline$(0,0,0)$ & 34.6 & 31.8 & 29.4 & 25.4 & 25.0 & 23.6 & 25.6 & 23.3 & 22.5 & 19.8 \\
\hline$(1,0,0)$ & 32.4 & 30.5 & 26.4 & 23.7 & 23.5 & 23.3 & 21.8 & 21.8 & 20.7 & 19.0 \\
\hline$(0,1,0)$ & 31.5 & 31.5 & 26.8 & 24.3 & 25.3 & 23.8 & 22.6 & 20.1 & 20.9 & 20.7 \\
\hline$(0,0,1)$ & 30.9 & 29.4 & 26.2 & 24.7 & 23.5 & 21.4 & 21.8 & 21.6 & 19.7 & 20.0 \\
\hline$(1,1,0)$ & 28.6 & 26.3 & 23.1 & 24.0 & 22.6 & 22.7 & 23.6 & 19.9 & 18.8 & 21.8 \\
\hline$(1,0,1)$ & 29.8 & 26.0 & 23.9 & 24.1 & 24.3 & 22.0 & 21.6 & 19.7 & 18.6 & 19.0 \\
\hline$(0,1,1)$ & 27.5 & 25.4 & 23.2 & 21.7 & 22.4 & 23.1 & 20.4 & 21.4 & 19.2 & 18.8 \\
\hline$(1,1,1)$ & 24.8 & 24.6 & 20.5 & 21.3 & 22.6 & 23.7 & 21.1 & 19.7 & 19.8 & 19.1 \\
\hline
\end{tabular}

\section{Estimation methodology}

\subsection{Overskilling and state dependence}

The first research question we address relates to the analysis of the probability of being currently overskilled, with a particular emphasis on the impacts of past overskilling, comparing individuals across their educational achievement. The outcome variable is dichotomous: 1 if overskilled and 0 if well-matched. We use a Dynamic Random Effects Probit model. We write the latent equation as: 
$O S_{i t}^{*}=\sum_{l=1}^{3} \gamma_{l} O S_{i t-l}+X_{i t}^{\prime} \beta+\alpha_{i}+u_{i t}$

where $i=1, \ldots, N$ denotes individuals observed over $t=4, \ldots, T$ periods. $O S_{i t}^{*}$ is the latent dependent variable for being overskilled, with the observable outcome $O S_{i t}=$ 1 if $O S_{i t}^{*} \geq 0$ and $=0$ otherwise. $O S_{i t-l}$ represent the three lags of the dependent variable and the $\gamma_{l}$ are the coefficients associated with the lags which are to be estimated. $X_{i t}$ is a matrix of individual and workplace characteristics (including a constant) which are allowed to be both time-variant and invariant. $\alpha_{i}$ is the individualspecific random component capturing the effect of time-invariant individual unobserved heterogeneity and $u_{i t}$ is an idiosyncratic error term distributed $N\left(0, \sigma_{u}^{2}\right)$. Two subtle but nonetheless serious estimation problems would arise if Equation (1) were to be estimated using a standard random effects framework.

The first problem would result from the often criticised as unrealistic assumption of zero correlation between the individual effect $\alpha_{i}$ and the explanatory variables $X_{i t}$ in the random effects model. This can be resolved using the method proposed by Mundlak (1978). This is done by assuming that the relationship between $\alpha_{i}$ and the means of the time-varying $x$-variables can be written as $\alpha_{i}=\bar{X}_{i}^{\prime} \delta+\varepsilon_{i}$, where $\varepsilon_{i} \sim$ iid follows the normal distribution and is independent of $X_{i t}$ and $u_{i t}$ for all $i$ and t. In practice Mundlak corrections can be applied by including in the right-hand side of Equation (1) the individual (over time) means for each of the time-varying explanatory variables.

The second problem arises from the possibility that the lagged dependent variable in the right-hand side of Equation (1) may be correlated with the error terms. This issue is known as the initial conditions problem. It was first examined in detail by Heckman 
(1981), who proposed an estimator incorporating a linear approximation of the latent dependent variable at the initial period which is used to express the joint probability of the observed sequence of individuals' experiences, given the individual effect $\alpha_{i}$. Alternative, less computation-intense estimators have been proposed, notably by Orme (1997), Arulampalam and Stewart (2009), and Wooldridge (2005). ${ }^{5}$ This paper follows the method of Wooldridge (2005) and combines it with the Mundlak (1978) method to estimate the following equation:

$O S_{i t}^{*}=\sum_{l=1}^{3} \gamma_{l} O S_{i t-l}+X_{i t}^{\prime} \beta+\bar{X}_{i}^{\prime} \delta+\theta O S_{i 1}+\varepsilon_{i}+u_{i t}$

with the observable outcome $O S_{i t}=1$ if $O S_{i t}^{*} \geq 0$ and $=0$ otherwise, where $O S_{i 1}$ represents the first observation of the binary dependent variable for the individual $i$.

\subsection{The effect of past overskilling on wages}

The second research question we address is whether wage penalties are influenced by self-persistence in overskilling mismatch. Do we observe wage penalties due to overskilling? If we do, how long does it take for an individual to recover from the penalties? That is, to what extent will the self-perpetuation of overskilling also cause the self-perpetuation of lower wages? We want to know whether overskilling scarring is prevalent for all educational levels and, if not, which educational pathway leads to the most and least scarring. Is this phenomenon mostly concentrated at both ends of the education spectrum, with school dropouts and university graduates being more exposed to this risk?

\footnotetext{
${ }^{5}$ Arulampalam and Stewart (2009) put Heckman's and the other estimators cited above to the test. They emphasise the benefits obtained from using the Mundlak correction and point out that all estimators provide similar results. Consequently, we made the choice of the Wooldridge (2005) method for the purpose of this research.
} 
In an attempt to answer these questions, we estimate two models, both of which consist of estimating the conditional mean wages using a conventional Mincer earnings function and utilising the panel structure of the data. We start by using a pooled OLS to estimate the equation below

$$
\ln w_{i t}=a_{0}+a_{1} O S_{i t}+a_{2} O S_{i t-1}+a_{3} O S_{i t-2}+a_{4} O S_{i t-3}+\beta X_{i t}+\varepsilon_{i t}
$$

The dependent variable is the logarithm of hourly wages. The lasting effect of overskilling mismatch on the log of hourly wages is captured by a set of four dummy variables indicating the employees' skill mismatch status for the current and the past three waves. The estimates for each of these 'lagged overskilling' variables indicate the magnitude of the wage penalties caused by previous spells of overskilling mismatch. We use other relevant personal and workplace characteristics as control variables in the estimations, including age, marital status, remoteness, migration background, firm size, tenure with current employer and industry dummies.

Since pooled regression estimates are always subject to biases due to unobserved systematic individual differences in the sample, we also use panel estimation which controls for time invariant unobserved individual heterogeneity and allows us to come closer to making inferences about causal effects. We estimate the earnings equation using a random effects model augmented with Mundlak (1978) corrections to control for unobserved time-invariant individual heterogeneity

$\ln w_{i t}=a_{0}+a_{1} O S_{i t}+a_{2} O S_{i t-1}+a_{3} O S_{i t-2}+a_{4} O S_{i t-3}+b X_{i t}+\xi_{1} \overline{O S}_{i}+\xi_{2} \bar{X}_{i}+v_{i t}$

where $\overline{O S}_{i}$ and $\bar{X}_{i}$ are the time averages of $M_{i t}$ and time variant elements of $X_{i t}$ for individual i, respectively. 


\section{Regression results}

\subsection{The effect of past overskilling on current overskilling: Probit analysis}

Results are generated using the dynamic random effects panel probit specification discussed in the methodology section and are presented in Table 4.

Table 4 Dynamic probit estimations of overskilling by educational level

\begin{tabular}{|c|c|c|c|c|c|}
\hline & $\begin{array}{c}\text { University } \\
\text { degrees } \\
\text { Marginal } \\
\text { effects } \\
\text { (z) }\end{array}$ & $\begin{array}{c}\text { Diplomas } \\
\text { Marginal } \\
\text { effects } \\
(\mathrm{z})\end{array}$ & $\begin{array}{c}\text { Certificates } \\
\text { III/IV } \\
\text { Marginal } \\
\text { effects } \\
(\mathrm{z}) \\
\end{array}$ & $\begin{array}{c}\text { Only } \\
\text { completed } \\
\text { school } \\
\text { Marginal } \\
\text { effects } \\
(\mathrm{z}) \\
\end{array}$ & $\begin{array}{c}\text { Did not } \\
\text { complete } \\
\text { school } \\
\text { Marginal } \\
\text { effects } \\
\text { (z) }\end{array}$ \\
\hline Overskilling at $t-1$ & $\begin{array}{l}0.150 \\
(7.37)\end{array}$ & $\begin{array}{l}0.210 \\
(5.58)\end{array}$ & $\begin{array}{l}0.198 \\
(8.57)\end{array}$ & $\begin{array}{l}0.188 \\
(6.98)\end{array}$ & $\begin{array}{c}0.231 \\
(10.76)\end{array}$ \\
\hline Overskilling at $t-2$ & $\begin{array}{l}0.053 \\
(4.23)\end{array}$ & $\begin{array}{l}0.137 \\
(4.80)\end{array}$ & $\begin{array}{l}0.153 \\
(8.11)\end{array}$ & $\begin{array}{l}0.148 \\
(6.43)\end{array}$ & $\begin{array}{c}0.195 \\
(10.51)\end{array}$ \\
\hline Overskilling at $t-3$ & $\begin{array}{l}0.043 \\
(3.62)\end{array}$ & $\begin{array}{l}0.088 \\
(3.43)\end{array}$ & $\begin{array}{l}0.087 \\
(5.06)\end{array}$ & $\begin{array}{l}0.083 \\
(3.89)\end{array}$ & $\begin{array}{l}0.098 \\
(5.29)\end{array}$ \\
\hline $\begin{array}{l}\text { Overskilling at } \\
\text { initial period }\end{array}$ & $\begin{array}{l}0.089 \\
(5.88)\end{array}$ & $\begin{array}{l}0.064 \\
(2.36)\end{array}$ & $\begin{array}{l}0.066 \\
(3.66)\end{array}$ & $\begin{array}{l}0.143 \\
(5.36)\end{array}$ & $\begin{array}{l}0.115 \\
(5.37)\end{array}$ \\
\hline Female & $\begin{array}{l}0.003 \\
(0.32)\end{array}$ & $\begin{array}{l}-0.044 \\
(-2.25)\end{array}$ & $\begin{array}{l}0.011 \\
(0.72)\end{array}$ & $\begin{array}{l}-0.02 \\
(-1.02)\end{array}$ & $\begin{array}{l}-0.028 \\
(-1.48)\end{array}$ \\
\hline Occupation tenure & $\begin{array}{l}0.001 \\
(0.77)\end{array}$ & $\begin{array}{l}0.004 \\
(2.24)\end{array}$ & $\begin{array}{l}0.000 \\
(0.36)\end{array}$ & $\begin{array}{l}0.003 \\
(1.17)\end{array}$ & $\begin{array}{l}-0.001 \\
(-0.58)\end{array}$ \\
\hline Hours worked & $\begin{array}{l}-0.003 \\
(-4.75)\end{array}$ & $\begin{array}{l}-0.005 \\
(-3.21)\end{array}$ & $\begin{array}{l}-0.003 \\
(-2.86)\end{array}$ & $\begin{array}{l}-0.002 \\
(-1.15)\end{array}$ & $\begin{array}{l}-0.003 \\
(-2.02)\end{array}$ \\
\hline Firm size up to 4 & $\begin{array}{l}-0.021 \\
(-1.00)\end{array}$ & $\begin{array}{l}-0.065 \\
(-1.88)\end{array}$ & $\begin{array}{c}-0.018 \\
(-0.5)\end{array}$ & $\begin{array}{l}-0.057 \\
(-1.16)\end{array}$ & $\begin{array}{l}-0.013 \\
(-0.29)\end{array}$ \\
\hline Firm size 5-9 & $\begin{array}{l}-0.023 \\
(-1.45)\end{array}$ & $\begin{array}{l}-0.017 \\
(-0.42)\end{array}$ & $\begin{array}{l}-0.008 \\
(-0.26)\end{array}$ & $\begin{array}{l}-0.039 \\
(-0.92)\end{array}$ & $\begin{array}{l}-0.041 \\
(-0.98)\end{array}$ \\
\hline Firm size 10-19 & $\begin{array}{l}-0.019 \\
(-1.36)\end{array}$ & $\begin{array}{l}-0.037 \\
(-1.09)\end{array}$ & $\begin{array}{l}0.057 \\
(1.77)\end{array}$ & $\begin{array}{l}-0.014 \\
(-0.34)\end{array}$ & $\begin{array}{l}-0.046 \\
(-1.23)\end{array}$ \\
\hline Firm size $20-49$ & $\begin{array}{c}-0.01 \\
(-0.82)\end{array}$ & $\begin{array}{l}-0.020 \\
(-0.64)\end{array}$ & $\begin{array}{l}-0.005 \\
(-0.22)\end{array}$ & $\begin{array}{l}-0.030 \\
(-0.86)\end{array}$ & $\begin{array}{l}-0.049 \\
(-1.53)\end{array}$ \\
\hline Sample size & 6736 & 2150 & 4819 & 3041 & 4439 \\
\hline Log likelihood & -1890.05 & -737.25 & -1851.62 & -1349.66 & -2098.35 \\
\hline
\end{tabular}


We estimate the probability for employees to report being currently overskilled in their job, with a particular emphasis on the effect of past experiences of skill mismatch on these probabilities. The impact of previous spells of overskilling is captured through the inclusion of three lagged dependent variables in the equations.

We estimate the three-lag model by educational level to highlight the differences with regard to the scarring effect of overskilling. Table 4 shows that the effect of previous overskilling mismatch on present overskilling is positive and diminishes overtime for all educational categories but the intensity differs by education level.

Overskilling is the least persistent among university degree holders. Those experiencing skill mismatch one year earlier are 15 per cent more likely than their well-matched comparators to be overskilled a year later. By contrast, the difference in probability associated to the first lag goes up to 23.1 per cent for high school noncompleters, (which is about 54 per cent higher than the university graduates). Looking three years back, the differences between university graduates and all others is even more striking. A spell of overskilling three years down the track keeps altering the probability of being currently overskilled, even for the university graduates. However, it only increases their overskilling probability by 4.3 per cent, which is about half of the effect observed for all other educational levels (ranging from 8.3 per cent for Year 12 graduates and 9.8 per cent for those who did not finish high school). Altogether, our results show that while persistence is still strong for all educational levels after three years, university graduates show the lowest self-persistence among all other workers, and those who do not finish high school show the highest. The profile of overskilling mismatch self-persistence is fairly similar for all other educational pathways, with estimates around 18 to 20 per cent for the first lag, 13 to 15 per cent for the second lag and around 9 per cent for the third lag. 


\subsection{Self-persistence of mismatch: The effect of past overskilling mismatch on current overskilling mismatch}

As we mentioned earlier, one of the main interpretational disadvantages of the results we presented in Table 4 is that each estimate is calculated for the average person. While this is usually a good way to think of estimates (it makes them comparable), it confuses our interpretation when we use lagged dependent variables on the right hand side of the equation. Although the results are mathematically correct, they do not necessarily tell us exactly what we want them to tell us. We explain this by way of example. In Table 4, the marginal effect of the second overskilling lag takes the value of 15.3 per cent. What this tells us is that if we take a person who has all their characteristics set at the average person's level, then the probability that this 'average' person will be overskilled in the present period is 15.3 per cent higher if they were overskilled two years back, than if they were well-matched two years back. However, note that since we are dealing with the second lag, this also assumes that the previous lag and the subsequent lag variables are also set at their average values. While this may be mathematically correct, it is very hard to interpret. Is there an intuitively interpretable meaning for a lagged effect that is conditional on another lagged effect that takes the mean sample value? To overcome this problem we use the estimation results to calculate a number of scenarios which we present below in Table 5 . The objective of Table 5 is to make comparisons between individuals with different past overskilling experiences and to show these comparisons by educational level. For each scenario, we compute the associated probabilities of being currently mismatched. This technique allows us to compare the effect of past spells of overskilling between two employees with the same educational pathway, and to establish whether or not self-persistence of overskilling mismatch deepens as time 
goes by, and, to a degree also to form an opinion as to whether this deepening differs by educational level.

Table 5 Estimated overskilling probabilities by educational level and scenario of overskilling

\begin{tabular}{|c|c|c|c|c|c|c|c|c|c|c|}
\hline \multirow[b]{2}{*}{ Scenario } & \multicolumn{2}{|c|}{ University degrees } & \multicolumn{2}{|c|}{ Diplomas } & \multicolumn{2}{|c|}{ Certificates III/IV } & \multicolumn{2}{|c|}{$\begin{array}{l}\text { Only completed } \\
\text { school }\end{array}$} & \multicolumn{2}{|c|}{$\begin{array}{c}\text { Did not complete } \\
\text { school }\end{array}$} \\
\hline & $\begin{array}{c}\text { Predicted } \\
\text { probability }\end{array}$ & $\begin{array}{c}\text { Overskilling } \\
\text { difference }\end{array}$ & $\begin{array}{c}\text { Predicted } \\
\text { probability }\end{array}$ & $\begin{array}{c}\text { Overskilling } \\
\text { difference }\end{array}$ & $\begin{array}{c}\text { Predicted } \\
\text { probability }\end{array}$ & $\begin{array}{c}\text { Overskilling } \\
\text { difference }\end{array}$ & $\begin{array}{c}\text { Predicted } \\
\text { probability }\end{array}$ & $\begin{array}{c}\text { Overskilling } \\
\text { difference }\end{array}$ & $\begin{array}{c}\text { Predicted } \\
\text { probability }\end{array}$ & $\begin{array}{c}\text { Overskilling } \\
\text { difference }\end{array}$ \\
\hline 000 & 0.046 & & 0.063 & & 0.084 & & 0.110 & & 0.129 & \\
\hline 100 & 0.180 & 0.133 & 0.236 & 0.174 & 0.253 & 0.169 & 0.269 & 0.159 & 0.324 & 0.195 \\
\hline 110 & 0.280 & 0.100 & 0.443 & 0.207 & 0.464 & 0.211 & 0.449 & 0.180 & 0.547 & 0.223 \\
\hline 111 & 0.380 & 0.100 & 0.598 & 0.155 & 0.602 & 0.138 & 0.563 & 0.114 & 0.661 & 0.114 \\
\hline
\end{tabular}

Note: Probabilities are based on the overskilling estimations presented in Table 4.

Table 5 contains four scenarios which correspond to a typically deepening overskilling mismatch experience in the last three years, represented by the estimated three-lag variables. The first scenario is when someone was never overskilled in the last three years. The second is when they were overskilled only in the previous year. The third is when they were overskilled in the previous two years, and the fourth one is when they were overskilled in all three past years. The intuition of a deepening overskilling experience is obvious. There are also other overskilling combinations and we have experimented with them to find that the scenarios we present here are a good representation of the overskilling self-persistence estimation. For convenience of presentation, we shall identify these scenarios with a set of binary codes, with ' 1 ' meaning that the employee was overskilled in the period considered and ' 0 ' if they were not. We use the three-lag model estimates in order to compute the probabilities attached to each scenario. Hence, the scenario '000' stands for an employee who has been well-matched throughout the last three years. The scenario denoted by ' 100 ' represents an individual who was overskilled in the previous year but was wellmatched in the two years before that, and so on. We compare probabilities for the 
scenarios ' 000 ', ' 100 ', ' 110 ', and ' 111 ' and we present the results alongside their change between each year for each educational level. A university graduate who was never before overskilled (the 000 type) has a 4.6 per cent probability of becoming overskilled. By contrast, another university graduate who was overskilled in all three preceding years (the 111 type) has a 38 per cent probability of becoming overskilled. Note that the probability difference of $33.4(=38-4.6)$ is conditional on both graduates having the same (average graduate) characteristics. We do not have any comparison at hand from the literature to evaluate the size of this probability, but a 33.4 per cent probability to continue being under-utilised appears high, and overskilling mismatch appears to be highly self-persistent. Still, university graduates produce by far the lowest overskilling mismatch self-persistence estimate. The highest estimate comes from those who did not finish high school, where the ' 000 ' and ' 111 ' types have a probability of 12.9 and 66.1 per cent respectively, with a probability difference of $53.2(=66.1-12.9)$. The probability differences can be interpreted as the degree of self-persistence of overskilling mismatch, and they start with 33.4 per cent for university graduates, 53.5 per cent for VET diploma graduates, 51.8 per cent for certificates III/IV graduates, 45.3 per cent for Year 12 graduates, and 53.2 per cent for those without high school completion. It is very clear that the main difference lies between university graduates and the rest, with perhaps something to say for the case of those without a post-school qualification where those who finished school appear to be doing much better than those who did not. It should be noted that whereas we can make comparisons within each of the educational level groups, especially in terms of the causal effect of past overskilling on current overskilling, we should not make any statistical comparisons about the absolute levels of overskilling mismatch between different educational levels, as the estimates we present do not control for 
any differences between any two groups. What we can compare is the way in which the different types of experiences vary by education.

\subsection{The effect of past overskilling on wages}

This section estimates the effect of overskilling on wages. There already exists sufficient and robust evidence on the deleterious effect of current overskilling mismatch on the current wages of the overskilled. This evidence shows that being overskilled is associated with lower wages at the population level, and becoming overskilled causes lower wages at the individual level. This section extends the evidence by investigating how having been overskilled in the past may have a lasting effect on wages. To this purpose, we present two sets of earnings models, a pooled OLS model and a random effects model augmented with Mundlak corrections, both estimated by educational level in keeping with the rest of this analysis. We incorporate lagged overskilling variables to examine whether past overskilling mismatch (at time t-1, t-2 and t-3) may have an influence on current wages. These regressions provide a mean effect; that is, they tell us how the mean wage for all people who belong to each educational category may be influenced by overskilling. We present the linear regression results in Table 6 below. 
Table 6 Wage estimation by education level (log hourly wage)

\begin{tabular}{|c|c|c|c|c|c|c|c|c|c|c|}
\hline & \multirow{2}{*}{\multicolumn{2}{|c|}{$\begin{array}{c}\text { University } \\
\text { degrees } \\
\text { Coef } \\
\text { (t ratio) }\end{array}$}} & \multirow{2}{*}{\multicolumn{2}{|c|}{$\begin{array}{c}\text { Diplomas } \\
\text { Coef } \\
\text { (t ratio) } \\
\end{array}$}} & \multirow{2}{*}{\multicolumn{2}{|c|}{$\begin{array}{c}\text { Certificates } \\
\text { III/IV } \\
\text { Coef } \\
\text { (t ratio) } \\
\end{array}$}} & \multirow{2}{*}{\multicolumn{2}{|c|}{$\begin{array}{l}\text { Only completed } \\
\text { school } \\
\text { Coef } \\
\text { (t ratio) }\end{array}$}} & \multirow{2}{*}{\multicolumn{2}{|c|}{$\begin{array}{c}\text { Did not } \\
\text { complete schoo } \\
\text { Coef } \\
\text { (t ratio) } \\
\end{array}$}} \\
\hline & & & & & & & & & & \\
\hline & $\begin{array}{c}\text { Pooled } \\
\text { OLS }\end{array}$ & $\begin{array}{c}\text { Panel } \\
\text { REM }\end{array}$ & $\begin{array}{l}\text { Pooled } \\
\text { OLS }\end{array}$ & $\begin{array}{c}\text { Panel } \\
\text { REM }\end{array}$ & $\begin{array}{c}\text { Pooled } \\
\text { OLS }\end{array}$ & $\begin{array}{c}\text { Panel } \\
\text { REM }\end{array}$ & $\begin{array}{c}\text { Pooled } \\
\text { OLS }\end{array}$ & $\begin{array}{c}\text { Panel } \\
\text { REM }\end{array}$ & $\begin{array}{c}\text { Pooled } \\
\text { OLS }\end{array}$ & $\begin{array}{c}\text { Panel } \\
\text { REM }\end{array}$ \\
\hline $\begin{array}{l}\text { Overskilling } \\
\text { at } t\end{array}$ & $\begin{array}{l}-0.065 \\
(-3.87)\end{array}$ & $\begin{array}{l}-0.030 \\
(-1.92)\end{array}$ & $\begin{array}{l}-0.072 \\
(-3.20)\end{array}$ & $\begin{array}{l}-0.029 \\
(-1.41)\end{array}$ & $\begin{array}{l}-0.037 \\
(-2.82)\end{array}$ & $\begin{array}{l}-0.009 \\
(-0.68)\end{array}$ & $\begin{array}{l}-0.030 \\
(-1.84)\end{array}$ & $\begin{array}{l}-0.037 \\
(-2.28)\end{array}$ & $\begin{array}{l}-0.051 \\
(-3.34)\end{array}$ & $\begin{array}{l}-0.010 \\
(-0.73)\end{array}$ \\
\hline $\begin{array}{l}\text { Overskilling } \\
\text { at } t-1\end{array}$ & $\begin{array}{l}-0.064 \\
(-4.08)\end{array}$ & $\begin{array}{l}-0.041 \\
(-2.56)\end{array}$ & $\begin{array}{l}-0.044 \\
(-2.11)\end{array}$ & $\begin{array}{l}-0.008 \\
(-0.38)\end{array}$ & $\begin{array}{l}-0.020 \\
(-1.57)\end{array}$ & $\begin{array}{l}-0.004 \\
(-0.40)\end{array}$ & $\begin{array}{l}-0.023 \\
(-1.53)\end{array}$ & $\begin{array}{c}-0.02 \\
(-1.29)\end{array}$ & $\begin{array}{l}-0.041 \\
(-3.18)\end{array}$ & $\begin{array}{l}-0.010 \\
(-0.82)\end{array}$ \\
\hline $\begin{array}{l}\text { Overskilling } \\
\text { at } t-2\end{array}$ & $\begin{array}{l}-0.067 \\
(-4.89)\end{array}$ & $\begin{array}{l}-0.031 \\
(-2.86)\end{array}$ & $\begin{array}{l}-0.051 \\
(-2.55)\end{array}$ & $\begin{array}{l}-0.016 \\
(-0.99)\end{array}$ & $\begin{array}{l}-0.003 \\
(-0.24)\end{array}$ & $\begin{array}{l}0.011 \\
(1.11)\end{array}$ & $\begin{array}{l}-0.024 \\
(-1.49)\end{array}$ & $\begin{array}{l}-0.023 \\
(-1.62)\end{array}$ & $\begin{array}{l}-0.015 \\
(-1.27)\end{array}$ & $\begin{array}{l}0.008 \\
(0.72)\end{array}$ \\
\hline $\begin{array}{l}\text { Overskilling } \\
\text { at } t-3\end{array}$ & $\begin{array}{l}-0.072 \\
(-5.03)\end{array}$ & $\begin{array}{l}-0.036 \\
(-3.12)\end{array}$ & $\begin{array}{l}-0.034 \\
(-1.66)\end{array}$ & $\begin{array}{l}0.018 \\
(1.18)\end{array}$ & $\begin{array}{l}-0.022 \\
(-1.64)\end{array}$ & $\begin{array}{l}-0.006 \\
(-0.57)\end{array}$ & $\begin{array}{l}-0.042 \\
(-2.68)\end{array}$ & $\begin{array}{l}-0.024 \\
(-1.84)\end{array}$ & $\begin{array}{l}-0.050 \\
(-3.94)\end{array}$ & $\begin{array}{l}-0.024 \\
(-2.37)\end{array}$ \\
\hline Female & $\begin{array}{l}-0.149 \\
(-8.5)\end{array}$ & $\begin{array}{l}-0.138 \\
(-7.49)\end{array}$ & $\begin{array}{l}-0.128 \\
(-3.83)\end{array}$ & $\begin{array}{c}-0.09 \\
(-2.73)\end{array}$ & $\begin{array}{l}-0.131 \\
(-6.55)\end{array}$ & $\begin{array}{l}-0.103 \\
(-4.80)\end{array}$ & $\begin{array}{l}-0.132 \\
(-5.00)\end{array}$ & $\begin{array}{l}-0.082 \\
(-3.18)\end{array}$ & $\begin{array}{l}-0.100 \\
(-4.27)\end{array}$ & $\begin{array}{l}-0.065 \\
(-2.49)\end{array}$ \\
\hline Age & $\begin{array}{l}0.041 \\
(6.56)\end{array}$ & $\begin{array}{l}0.127 \\
(11.9)\end{array}$ & $\begin{array}{l}0.040 \\
(3.81)\end{array}$ & $\begin{array}{l}0.117 \\
(5.69)\end{array}$ & $\begin{array}{l}0.021 \\
(3.86)\end{array}$ & $\begin{array}{l}0.091 \\
(7.73)\end{array}$ & $\begin{array}{l}0.028 \\
(3.15)\end{array}$ & $\begin{array}{l}0.119 \\
(7.53)\end{array}$ & $\begin{array}{l}0.024 \\
(4.39)\end{array}$ & $\begin{array}{l}0.113 \\
(7.52)\end{array}$ \\
\hline Age square & $\begin{array}{l}-0.045 \\
(-5.79)\end{array}$ & $\begin{array}{l}-0.074 \\
(-6.04)\end{array}$ & $\begin{array}{l}-0.048 \\
(-3.61)\end{array}$ & $\begin{array}{l}-0.074 \\
(-3.19)\end{array}$ & $\begin{array}{l}-0.024 \\
(-3.32)\end{array}$ & $\begin{array}{l}-0.041 \\
(-3.09)\end{array}$ & $\begin{array}{l}-0.031 \\
(-2.46)\end{array}$ & $\begin{array}{l}-0.072 \\
(-3.85)\end{array}$ & $\begin{array}{l}-0.025 \\
(-3.68)\end{array}$ & $\begin{array}{l}-0.067 \\
(-4.29)\end{array}$ \\
\hline Disability & $\begin{array}{l}-0.007 \\
(-0.34)\end{array}$ & $\begin{array}{l}0.002 \\
(0.14)\end{array}$ & $\begin{array}{l}-0.026 \\
(-0.79)\end{array}$ & $\begin{array}{l}0.034 \\
(1.60)\end{array}$ & $\begin{array}{l}-0.051 \\
(-2.75)\end{array}$ & $\begin{array}{l}0.011 \\
(0.98)\end{array}$ & $\begin{array}{l}-0.103 \\
(-4.10)\end{array}$ & $\begin{array}{l}-0.036 \\
(-1.87)\end{array}$ & $\begin{array}{l}-0.054 \\
(-2.50)\end{array}$ & $\begin{array}{l}0.005 \\
(0.39)\end{array}$ \\
\hline Married & $\begin{array}{l}0.056 \\
(3.14)\end{array}$ & $\begin{array}{l}0.016 \\
(0.79)\end{array}$ & $\begin{array}{l}0.059 \\
(1.92)\end{array}$ & $\begin{array}{l}-0.008 \\
(-0.28)\end{array}$ & $\begin{array}{l}0.064 \\
(3.6)\end{array}$ & $\begin{array}{l}-0.008 \\
(-0.42)\end{array}$ & $\begin{array}{l}0.052 \\
(2.17)\end{array}$ & $\begin{array}{l}0.007 \\
(0.27)\end{array}$ & $\begin{array}{l}0.067 \\
(2.84)\end{array}$ & $\begin{array}{l}-0.002 \\
(-0.06)\end{array}$ \\
\hline Urban & $\begin{array}{l}0.002 \\
(0.07)\end{array}$ & $\begin{array}{l}-0.033 \\
(-0.76)\end{array}$ & $\begin{array}{l}0.009 \\
(0.22)\end{array}$ & $\begin{array}{l}-0.064 \\
(-1.39)\end{array}$ & $\begin{array}{l}0.026 \\
(1.17)\end{array}$ & $\begin{array}{l}-0.055 \\
(-0.82)\end{array}$ & $\begin{array}{l}0.078 \\
(1.86)\end{array}$ & $\begin{array}{l}-0.091 \\
(-1.77)\end{array}$ & $\begin{array}{l}0.073 \\
(2.58)\end{array}$ & $\begin{array}{l}0.025 \\
(0.47)\end{array}$ \\
\hline $\begin{array}{l}\text { Father was } \\
\text { professional }\end{array}$ & $\begin{array}{c}0.02 \\
(1.18)\end{array}$ & $\begin{array}{l}0.024 \\
(1.35)\end{array}$ & $\begin{array}{l}0.025 \\
(0.63)\end{array}$ & $\begin{array}{l}0.039 \\
(0.95)\end{array}$ & $\begin{array}{l}0.081 \\
(2.96)\end{array}$ & $\begin{array}{l}0.046 \\
(1.65)\end{array}$ & $\begin{array}{l}0.019 \\
(0.63)\end{array}$ & $\begin{array}{l}0.036 \\
(1.28)\end{array}$ & $\begin{array}{l}0.107 \\
(3.24)\end{array}$ & $\begin{array}{l}0.082 \\
(2.46)\end{array}$ \\
\hline $\begin{array}{l}\text { Migrant ESP } \\
\text { country }\end{array}$ & $\begin{array}{c}0.06 \\
(2.27)\end{array}$ & $\begin{array}{l}0.061 \\
(2.17)\end{array}$ & $\begin{array}{l}0.067 \\
(1.22)\end{array}$ & $\begin{array}{l}0.043 \\
(0.92)\end{array}$ & $\begin{array}{c}0.000 \\
(-0.01)\end{array}$ & $\begin{array}{l}0.008 \\
(0.26)\end{array}$ & $\begin{array}{l}-0.045 \\
(-1.06)\end{array}$ & $\begin{array}{l}-0.050 \\
(-1.13)\end{array}$ & $\begin{array}{l}0.042 \\
(1.69)\end{array}$ & $\begin{array}{l}0.046 \\
(1.70)\end{array}$ \\
\hline $\begin{array}{l}\text { Migrant NESP } \\
\text { country }\end{array}$ & $\begin{array}{c}-0.056 \\
(-2.1)\end{array}$ & $\begin{array}{l}-0.045 \\
(-1.65)\end{array}$ & $\begin{array}{l}-0.062 \\
(-1.04)\end{array}$ & $\begin{array}{l}-0.034 \\
(-0.65)\end{array}$ & $\begin{array}{l}-0.055 \\
(-1.68)\end{array}$ & $\begin{array}{l}-0.036 \\
(-1.09)\end{array}$ & $\begin{array}{l}-0.026 \\
(-0.71)\end{array}$ & $\begin{array}{l}-0.030 \\
(-0.80)\end{array}$ & $\begin{array}{l}0.027 \\
(0.77)\end{array}$ & $\begin{array}{l}0.001 \\
(0.03)\end{array}$ \\
\hline $\begin{array}{l}\text { Australian born } \\
\text { ATSI }\end{array}$ & $\begin{array}{l}0.116 \\
(1.58)\end{array}$ & $\begin{array}{l}0.103 \\
(1.6)\end{array}$ & $\begin{array}{l}0.235 \\
(1.64)\end{array}$ & $\begin{array}{l}0.073 \\
(0.48)\end{array}$ & $\begin{array}{l}0.104 \\
(1.77)\end{array}$ & $\begin{array}{l}0.098 \\
(1.83)\end{array}$ & $\begin{array}{l}0.058 \\
(0.98)\end{array}$ & $\begin{array}{l}0.082 \\
(1.17)\end{array}$ & $\begin{array}{l}0.013 \\
(0.23)\end{array}$ & $\begin{array}{l}0.072 \\
(1.10)\end{array}$ \\
\hline Hours worked & $\begin{array}{l}-0.005 \\
(-6.12)\end{array}$ & $\begin{array}{l}-0.012 \\
(-15.1)\end{array}$ & $\begin{array}{l}-0.003 \\
(-2.51)\end{array}$ & $\begin{array}{l}-0.016 \\
(-8.91)\end{array}$ & $\begin{array}{l}-0.006 \\
(-7.84)\end{array}$ & $\begin{array}{l}-0.013 \\
(-12.2)\end{array}$ & $\begin{array}{l}-0.006 \\
(-3.45)\end{array}$ & $\begin{array}{l}-0.011 \\
(-8.07)\end{array}$ & $\begin{array}{c}-0.004 \\
(-3.1)\end{array}$ & $\begin{array}{l}-0.012 \\
(-9.18)\end{array}$ \\
\hline $\begin{array}{l}\text { Occupation } \\
\text { tenure }\end{array}$ & $\begin{array}{l}0.004 \\
(3.48)\end{array}$ & $\begin{array}{l}0.001 \\
(0.87)\end{array}$ & $\begin{array}{l}0.006 \\
(3.92)\end{array}$ & $\begin{array}{l}-0.001 \\
(-0.84)\end{array}$ & $\begin{array}{l}0.003 \\
(3.19)\end{array}$ & $\begin{array}{l}0.000 \\
(0.08)\end{array}$ & $\begin{array}{l}0.005 \\
(3.28)\end{array}$ & $\begin{array}{c}0.000 \\
(-0.13)\end{array}$ & $\begin{array}{l}0.001 \\
(1.19)\end{array}$ & $\begin{array}{l}-0.001 \\
(-0.81)\end{array}$ \\
\hline $\begin{array}{l}\text { Current job } \\
\text { tenure }\end{array}$ & $\begin{array}{l}0.002 \\
(1.99)\end{array}$ & $\begin{array}{l}0.003 \\
(2.27)\end{array}$ & $\begin{array}{l}0.006 \\
(3.44)\end{array}$ & $\begin{array}{l}0.000 \\
(0.00)\end{array}$ & $\begin{array}{l}0.001 \\
(1.15)\end{array}$ & $\begin{array}{c}0.000 \\
(-0.14)\end{array}$ & $\begin{array}{l}0.004 \\
(2.03)\end{array}$ & $\begin{array}{l}-0.001 \\
(-0.66)\end{array}$ & $\begin{array}{l}0.001 \\
(0.85)\end{array}$ & $\begin{array}{l}0.002 \\
(1.87)\end{array}$ \\
\hline $\begin{array}{l}\text { Firm size } \\
\text { up to } 4\end{array}$ & $\begin{array}{l}-0.247 \\
(-6.49)\end{array}$ & $\begin{array}{l}-0.061 \\
(-2.01)\end{array}$ & $\begin{array}{l}-0.128 \\
(-2.01)\end{array}$ & $\begin{array}{l}-0.033 \\
(-0.75)\end{array}$ & $\begin{array}{l}-0.199 \\
(-7.04)\end{array}$ & $\begin{array}{l}-0.090 \\
(-3.27)\end{array}$ & $\begin{array}{l}-0.199 \\
(-5.26)\end{array}$ & $\begin{array}{l}-0.104 \\
(-2.65)\end{array}$ & $\begin{array}{l}-0.122 \\
(-4.03)\end{array}$ & $\begin{array}{l}-0.047 \\
(-1.85)\end{array}$ \\
\hline $\begin{array}{l}\text { Firm size } \\
\text { 5-9 }\end{array}$ & $\begin{array}{l}-0.174 \\
(-5.84)\end{array}$ & $\begin{array}{l}-0.068 \\
(-2.78)\end{array}$ & $\begin{array}{l}-0.021 \\
(-0.54)\end{array}$ & $\begin{array}{c}-0.04 \\
(-1.07)\end{array}$ & $\begin{array}{c}-0.12 \\
(-5.65)\end{array}$ & $\begin{array}{l}-0.028 \\
(-1.40)\end{array}$ & $\begin{array}{l}-0.098 \\
(-3.33)\end{array}$ & $\begin{array}{c}-0.069 \\
(-1.9)\end{array}$ & $\begin{array}{l}-0.075 \\
(-3.03)\end{array}$ & $\begin{array}{l}-0.027 \\
(-1.28)\end{array}$ \\
\hline $\begin{array}{l}\text { Firm size } \\
10-19\end{array}$ & $\begin{array}{l}-0.113 \\
(-4.55)\end{array}$ & $\begin{array}{l}-0.032 \\
(-1.51)\end{array}$ & $\begin{array}{l}-0.107 \\
(-3.42)\end{array}$ & $\begin{array}{l}-0.065 \\
(-2.41)\end{array}$ & $\begin{array}{l}-0.104 \\
(-5.18)\end{array}$ & $\begin{array}{l}-0.034 \\
(-2.05)\end{array}$ & $\begin{array}{l}-0.116 \\
(-4.25)\end{array}$ & $\begin{array}{l}-0.077 \\
(-2.16)\end{array}$ & $\begin{array}{l}-0.058 \\
(-2.52)\end{array}$ & $\begin{array}{l}-0.023 \\
(-1.21)\end{array}$ \\
\hline $\begin{array}{l}\text { Firm size } \\
20-49\end{array}$ & $\begin{array}{l}-0.105 \\
(-6.01)\end{array}$ & $\begin{array}{l}-0.015 \\
(-1.14)\end{array}$ & $\begin{array}{l}-0.035 \\
(-1.18)\end{array}$ & $\begin{array}{l}-0.04 \\
(-1.96)\end{array}$ & $\begin{array}{l}-0.027 \\
(-1.50)\end{array}$ & $\begin{array}{l}-0.009 \\
(-0.65)\end{array}$ & $\begin{array}{l}-0.11 \\
(-4.32)\end{array}$ & $\begin{array}{l}-0.05 \\
(-2.35)\end{array}$ & $\begin{array}{l}-0.021 \\
(-0.93)\end{array}$ & $\begin{array}{l}-0.007 \\
(-0.42)\end{array}$ \\
\hline $\begin{array}{l}\text { Children aged } \\
5-14\end{array}$ & $\begin{array}{c}0.02 \\
(1.12)\end{array}$ & $\begin{array}{l}-0.008 \\
(-0.6)\end{array}$ & $\begin{array}{l}-0.009 \\
(-0.28)\end{array}$ & $\begin{array}{l}-0.039 \\
(-1.73)\end{array}$ & $\begin{array}{l}-0.021 \\
(-1.24)\end{array}$ & $\begin{array}{l}-0.003 \\
(-0.20)\end{array}$ & $\begin{array}{l}-0.031 \\
(-1.09)\end{array}$ & $\begin{array}{l}0.014 \\
(0.35)\end{array}$ & $\begin{array}{l}-0.018 \\
(-1.00)\end{array}$ & $\begin{array}{l}0.011 \\
(0.57)\end{array}$ \\
\hline $\begin{array}{l}\text { Children aged } \\
\text { under } 5\end{array}$ & $\begin{array}{l}0.056 \\
(2.66)\end{array}$ & $\begin{array}{l}-0.040 \\
(-2.11)\end{array}$ & $\begin{array}{l}0.030 \\
(0.69)\end{array}$ & $\begin{array}{l}-0.01 \\
(-0.31)\end{array}$ & $\begin{array}{l}0.046 \\
(2.15)\end{array}$ & $\begin{array}{l}0.047 \\
(2.11)\end{array}$ & $\begin{array}{l}0.020 \\
(0.70)\end{array}$ & $\begin{array}{l}-0.035 \\
(-1.50)\end{array}$ & $\begin{array}{l}-0.008 \\
(-0.28)\end{array}$ & $\begin{array}{l}0.012 \\
(0.44)\end{array}$ \\
\hline $\begin{array}{l}\text { Per cent of time } \\
\text { unemployed }\end{array}$ & $\begin{array}{l}-0.004 \\
(-3.26)\end{array}$ & $\begin{array}{l}-0.003 \\
(-3.17)\end{array}$ & $\begin{array}{l}-0.003 \\
(-1.75)\end{array}$ & $\begin{array}{l}-0.003 \\
(-0.97)\end{array}$ & $\begin{array}{l}-0.002 \\
(-1.89)\end{array}$ & $\begin{array}{l}-0.004 \\
(-4.21)\end{array}$ & $\begin{array}{c}0.000 \\
(-0.01)\end{array}$ & $\begin{array}{l}-0.005 \\
(-2.26)\end{array}$ & $\begin{array}{l}0.000 \\
(-0.43)\end{array}$ & $\begin{array}{l}-0.002 \\
(-2.21)\end{array}$ \\
\hline Union member & $\begin{array}{l}-0.019 \\
(-1.12)\end{array}$ & $\begin{array}{l}0.020 \\
(1.27)\end{array}$ & $\begin{array}{l}-0.040 \\
(-1.49)\end{array}$ & $\begin{array}{l}-0.020 \\
(-0.72)\end{array}$ & $\begin{array}{l}0.052 \\
(3.01)\end{array}$ & $\begin{array}{l}0.038 \\
(2.37)\end{array}$ & $\begin{array}{l}0.007 \\
(0.28)\end{array}$ & $\begin{array}{l}0.030 \\
(1.03)\end{array}$ & $\begin{array}{l}0.049 \\
(2.19)\end{array}$ & $\begin{array}{l}0.006 \\
(0.26)\end{array}$ \\
\hline Sample size & 6237 & & 2006 & & 4495 & & 2754 & & 4074 & \\
\hline
\end{tabular}

Note: Dependent variable is the log of hourly wages. Coefficients and t ratios are reported. Industry dummies in the regression but not presented here; Mundlak correction terms are included in the REM regression but not presented here. Full estimation results can be found in Appendix II. The unit of observation is person-years. HILDA waves 1-9. REM denotes random effects linear estimation with Mundlak corrections. 
Table 6 shows several interesting findings. First, educational level matters regarding the effect of past overskilling on present wages. University graduates have to live for many years with the effect of their past overskilling. Even overskilling that happened three years back appears to reduce present wages by 3.6 per cent. Our evidence suggests that the effect of overskilling mismatch is both serious and long-lasting, considering that the loss refers to annual income and can be cumulative in the sense that the overall effect of overskilling will consist of all annual effects put together. Evidence on diploma graduates is mixed, though it should be noted that this educational category is the least populous in the data set, and may suffer small-sample problems. Note that the cross-section results (Pooled OLS) suggest that, on average, past overskilling is associated with lower wages, but these results do not control for individual unobserved heterogeneity. Panel results do not show any effect of overskilling on wages, but this may be because there are not enough people in the Diploma category who change their overskilling status. Estimation is not sufficiently informative about the difference between cross-section and panel evidence for this category. By contrast, evidence on Certificate III/IV graduates is relatively clear cut: there is very little evidence to suggest that past overskilling has any effect on the present or future wages of VET graduates.

Moving to workers without post-school qualifications, we see that there is some evidence from the panel analysis for Year 12 graduates suggesting the presence of long-lasting overskilling wage penalties. The effect of overskilling increases with time, suggesting that this may be a problem area with strong self-persistence within a group that is generally low paid. A surprisingly strong panel coefficient for overskilling in the third lag only appears for those who did not complete high school. The statistical significance for both the pooled and the panel coefficients is too strong 
for us to choose to ignore this result, but its interpretation is difficult as no other panel coefficient is even remotely statistically significant (with all t-values below 1 and all coefficients -0.01 or less one cannot interpret this result with ease).

\subsection{Estimating scarring}

\subsubsection{Review of the scarring concept}

We begin with an explanation of the term scarring in the context of labour market outcomes. In the labour economics literature there are many adverse outcomes that are well-known to have a scarring effect on lifetime outcomes. The economic explanation of scarring is that there are labour market experiences that harm the level and (or) the development of individual human capital and the capacity to participate in the labour market in the long run, in that those who are subjected to these experiences develop a long-term labour market disadvantage. A scarring effect is presented as a disadvantage that is self-perpetuating for the individual and is clearly over and above any positive or negative effect that their individual characteristics may play regarding the presence or absence of this disadvantage. For example, youth under-employment and (or) unemployment may have long-lasting negative effects on the labour market participation (and subsequently general labour market performance) of those who are unfortunate enough to have these experiences (Bell and Blanchflower 2010). The increased youth unemployment that recessions cause has been shown to reduce lifetime participation and income for those who are subjected to it. Otherwise identical youths who grew up in a better macroeconomy have been shown to enjoy better lifetime labour market prospects. Another example of the phenomenon of scarring is long-term unemployment and the associated welfare dependence, which are known to cause scarring in the form of continuing long-term 
unemployment and welfare dependence (Heckman 1978). Scarring is often referred to as state dependence.

The authors of this paper have shown in previous publications that the phenomenon of overskilling has adverse labour market consequences in the form of short-term wage and job satisfaction losses. In this research, the main question is the degree to which the overskilling phenomenon is self-perpetuating in the long term. To do this, we estimate models which examine whether the scarring effect of overskilling lasts for three years. It is suggested that overskilling is self-perpetuating and long-lasting. Overskilling scarring is analogous to unemployment and under-employment scarring. This analogy is embedded in human capital theory, in that overskilling mismatch is a form of human capital under-utilisation, like under-employment and unemployment. The main difference is that unemployment and underemployment are expressed as lost product through under-utilisation in terms of working too few hours, while overskilling mismatch is expressed as lost product through under-utilisation in terms of using too few skills and abilities. Note that both forms of under-utilisation result in lower product and lower pay. As we show in this paper, overskilling is a form of under-utilisation that behaves in the same self-perpetuating way as the one suggested in the literature for unemployment and under-employment. We now turn to scarring and overskilling.

Scarring is a term that is used in this paper and has to be explained in simple terms. We have known for some time that the strength of the labour market outcomes associated with and (or) caused by overskilling varies considerably by educational pathway. This distinction has arisen from recent research (Mavromaras et al. 2009b) which utilised panel econometrics for the first time in the context of overskilling and showed that both the overskilling wage penalty and overskilling persistence are 
concentrated at the two ends of the educational distribution. When we incorporate in the model only the very recent past (in the form of the previous year's interview), it is first and foremost the degree holders who appear to suffer the highest wage penalty and who at the same time have the strongest persistence. Then there are those who have no qualifications beyond Year 10 at school and who suffer the next highest overskilling wage penalty and persistence. In between these two groups are those with Year 11 and Year 12 school completion and VET graduates who appear to suffer the minimal wage penalty and persistence.

For degree holders, conventional wisdom suggests that 'getting a degree' will increase expected earnings by a considerable percentage, so degree-level education is an unconditionally attractive pathway to follow. This information may be correct on average but it is incomplete, as it ignores the suggestion that the proportion of degree graduates who get it wrong (that is, those who end up being overskilled) will get it badly wrong (that is, they suffer a wage penalty and they can be trapped in their lower earnings status: they are 'scarred'). For Year 10 school graduates, scarring could be even worse news, as their earnings and employment circumstances fall from a much lower average level. The question regarding this group is ‘how bad can it get?' when someone who is at the bottom of the education or qualifications ladder ends up being overskilled. Thus, we define scarring as the position where an employee may be in a long-term overskilling position and where they may be suffering long-term wage losses as a consequence. The estimations we presented in the previous sections on state dependence and scarring allow us to build some relevant scenarios for examination. We do this in two stages. The first stage examines self-persistence alone, and the second stage examines self-persistence and wages combined. We use the model which examines the effect of past overskilling up to three years earlier. 


\subsubsection{Incorporating self-persistence in the calculation of expected wages}

In the previous sections we estimated the probability of overskilling mismatch selfpersistence and the wage losses that are caused by such mismatching. This section uses the estimates from these two steps in order to predict the expected wage losses for a number of scenarios. The set of scenarios mirrors those presented in Table 5, with four types of individuals (the 000 ’ never been overskilled; ‘100’ overskilled in the last year only; '110' overskilled in the last two years only; '111' overskilled in all past three years). We calculate expected current wages for each scenario and compare the losses in wages that can be attributed to overskilling self-persistence. The expected current wage for each type of individual is calculated as follows:

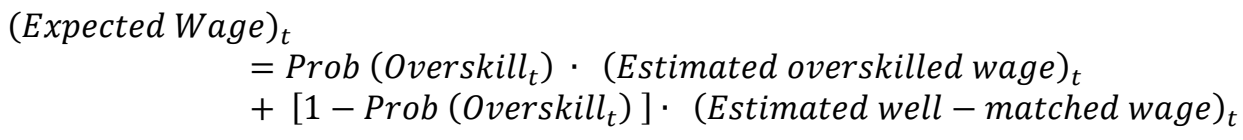

It is worth noting that both probability predictions and wage predictions are made at the individual level and they depend on the estimated level of overskilling mismatch self-persistence. Thus, both predictions are made to control for observed individual differences in the sample (which means that these are accounted for in the expected wage predictions) and for unobserved individual heterogeneity in both persistence and wage estimations (through the use of panel regression, which means that unobserved heterogeneity is comprehensively accounted for in the expected wage predictions we present). Given the data at hand, the evidence we present is the closest we can get to the estimation of the causal effect of past and current overskilling mismatch on the earnings of the overskilled in the Australian labour market. 
Table $7 \quad$ Scarring predictions by education level

\begin{tabular}{|c|c|c|c|c|c|c|c|c|c|c|}
\hline \multirow[t]{2}{*}{ Scenario } & \multicolumn{2}{|c|}{ University degrees } & \multicolumn{2}{|c|}{ Diplomas } & \multicolumn{2}{|c|}{ Certificates III/IV } & \multicolumn{2}{|c|}{$\begin{array}{l}\text { Only completed } \\
\text { school }\end{array}$} & \multicolumn{2}{|c|}{$\begin{array}{c}\text { Did not complete } \\
\text { school }\end{array}$} \\
\hline & $\begin{array}{l}\text { Expected } \\
\text { wage at } t\end{array}$ & $\begin{array}{c}\text { Wage } \\
\text { penalty }\end{array}$ & $\begin{array}{l}\text { Expected } \\
\text { wage at } t\end{array}$ & $\begin{array}{c}\text { Wage } \\
\text { penalty }\end{array}$ & $\begin{array}{l}\text { Expected } \\
\text { wage at } t\end{array}$ & $\begin{array}{c}\text { Wage } \\
\text { penalty }\end{array}$ & $\begin{array}{l}\text { Expected } \\
\text { wage at } t\end{array}$ & $\begin{array}{l}\text { Wage } \\
\text { penalty }\end{array}$ & $\begin{array}{l}\text { Expected } \\
\text { wage at } t\end{array}$ & $\begin{array}{c}\text { Wage } \\
\text { penalty }\end{array}$ \\
\hline$(0,0,0)$ & 30.59 & - & 25.24 & - & 22.59 & - & 21.36 & - & 19.63 & - \\
\hline$(1,0,0)$ & 29.26 & $-4.3 \%$ & 24.92 & $-1.3 \%$ & 22.46 & $-0.6 \%$ & 20.82 & $-2.5 \%$ & 19.39 & $-1.2 \%$ \\
\hline$(1,1,1)$ & 27.19 & $-11.1 \%$ & 24.69 & $-2.2 \%$ & 22.51 & $-0.4 \%$ & 19.64 & $-8.1 \%$ & 19.02 & $-3.1 \%$ \\
\hline
\end{tabular}

Table 7 offers some noteworthy findings. First, we only find evidence of deepening self-persistence for university graduates and Year 12 school graduates. Workers from all other educational levels may be experiencing overskilling mismatch, but it is not self-persistent and it does not get worse with time.

The main group that suffers from overskilling mismatch is university graduates. The earnings of a mismatched university graduate can be 11 per cent lower than that of a well-matched comparator. This is a massive difference which can have a large cumulative effect on future earnings and on lifetime income and wealth accumulation. The effect of overskilling mismatch is shown to deepen considerably from -4.3 per cent for the ' 100 ' type, to -7.6 per cent for the ' 110 ' type and -11.1 per cent for the ' 111 ' type. It is clear that while there will be fewer university graduates who will become overskilled, they will suffer considerably more per person than for any other educational category. A similar but weaker picture arises for Year 12 school graduates, with wage losses being -2.5 per cent for ' 100 ', -5.4 per cent for ' 110 ', and 8.1 per cent for ' 111 '. Diploma graduates show little overall effect of overskilling mismatch on wages, but the reader should be reminded that the wage estimations suggest that this is a diverse group, and that this diversity may mask some significant effects. Further, the diploma graduates' sample may be too small for the detail that is asked for by the estimation methodology with three lags. 
VET graduates with Certificate III/IV clearly do not suffer from overskilling in the long run. While there is evidence in this paper, and in the literature, that VET graduates may suffer moderate wage losses when they become overskilled, our findings suggest that these wage losses are short-lived. This finding has been consistent throughout our estimations and presents a picture that is in sharp contrast to that for university graduates.

Finally, the findings for those without post-school qualifications are diverse. As we mentioned, Year 12 school graduates look very similar to university graduates and they suffer the second highest wage losses. However, those without Year 12 school completion provide us with no clear picture regarding wage losses due to overskilling, with the exception of the ' 111 ' type where a strong negative effect is indicated. ${ }^{6}$

\section{Conclusion}

The research findings of this paper have highlighted many hitherto unknown aspects of skills under-utilisation in general, and overskilling mismatch in particular. Here we discuss how these findings can help us to understand the labour market disadvantages that are caused by overskilling mismatch and whether and how VET may protect workers from such disadvantages.

The first advance of this paper was to define scarring within the context of mismatched employed workers and then to design the appropriate estimation methodology to implement this definition empirically. This definition was based on the concept of self-persistence of mismatch, the origins of which lie in the literature of

\footnotetext{
${ }^{6}$ Presumably this is the consequence of the strong coefficient for the $t-3$ lag in the less than year 12 education category. As we have already discussed, we do not have any explanation for this result, hence we warn the reader against making any strong interpretation regarding this finding.
} 
state dependence and long-term scarring, known to be caused by long-term unemployment, participation in welfare programs, under-employment and other adverse labour market outcomes. All these phenomena are scarring in the sense that they contain elements of self perpetuation: once they occur they are self-feeding and self-persistent, and their mere presence increases the probability of their continuation. Our empirical analysis provided strong evidence for the presence of both persistence and self-persistence of overskilling mismatch. Strong persistence implies that the supply of skills and abilities by workers does not match the requirements for skills and abilities of jobs in the economy. Between 15 and 30 per cent of employed workers report themselves as overskilled, a percentage that decreases with educational level. These high percentages suggest that the production process in the broader economy does not use the skills that are present in the workforce, and that any means on offer through which this persistence may be reduced are not adequate for reducing persistent mismatch. The wage losses (estimated in this paper) and the job satisfaction losses (Mavromaras et al. 2012c) associated with overskilling mismatch are an indication that overskilling reduces the welfare of workers and are a reflection of possible productivity losses.

Further analysis reveals high levels of self-persistence as well. That is, not only do we find that there are many workers who are overskilled for longer periods of time, but that their past overskilling makes their present and future overskilling more likely. We find that after we have controlled for the observed characteristics of the workers and their economic circumstances, as well as their unobserved individual characteristics through appropriate regression analysis, overskilling mismatch is intensely selfpersistent for workers at all educational levels. Even without any priors, the estimated strength of self-persistence is surprising, especially for those who have not completed 
their high school education and for VET graduates. School graduates who completed Year 12 education show slightly lower and university graduates show much lower, but still sizeable, self-persistence. We mentioned when we presented these results in the previous sections that we do not have any comparative research results to use as a benchmark for the numbers we have estimated, so our discussion relies on our judgement and our common sense expectations about the extent of self-persistent mismatch in the economy. We believe that the finding that a university graduate who has been overskilled three years in a row has a 38 per cent probability of being overskilled in the next year, as compared with another university graduate who was well-matched three years in a row, and has a 4.6 per cent probability of being overskilled in the next year (a difference between the persistently overskilled and the persistently well-matched graduates of 33.4 percentage points), illustrating the importance of individuals finding a job which is an appropriate match. The difference between the persistently overskilled and the persistently well-matched rises to just below 50 percentage points for Year 12 school graduates and above 50 percentage points for all other educational categories. By any standard, these are very high percentages, reflecting strong imbalances. But, do these imbalances matter? And if so, by how much do they matter?

This research went further than just establishing the over-time incidence of overskilling mismatch self-persistence, and we investigated whether any quantifiable scarring effects may result from it. We defined scarring as the situation where selfpersistence of the probability to remain overskilled is translated into long-run wage losses. We have used the well-established overskilling wage penalty as a measure of the wage losses that can be caused by self-persistent overskilling mismatch. By incorporating overskilling penalties in the picture, we construct a monetary measure 
of overskilling mismatch losses. This is important, because there could be an argument that someone may well be overskilled, but if they do not suffer any financial penalty from being overskilled, we lack concrete evidence of any welfare or productivity loss and, therefore, we should not worry about workers who may be overskilled. Where we find evidence of wage losses, we argue that these losses are a quantification of welfare losses in the form of foregone production and under-utilised human capital. Clearly, this argument cannot be readily transferred to the macroeconomic sphere, as demand for skills derives from the demand for the goods that these skills can produce. Whether the necessary actual or latent product demand is present or not is a broader national question, which cannot be answered here. However, the macroeconomic conditions in Australia make the assumption of longrun excess labour supply rather improbable.

The calculation of the impact of overskilling mismatch self-persistence on wages is revealing. We find that although university graduates are the educational category with the lowest persistence and self-persistence of overskilling mismatch, those who become overskilled sustain by far the worst per person losses in wages amongst all other overskilled workers. Results suggest that it is the better paid university graduates who suffer the highest overskilling per person wage losses. This may suggest that higher graduate wages may be offered as compensation for taking higher risks. That is, while graduates can expect that their lifetime earnings on average will be higher than those of non-graduates, there is a higher variance, so that such an outcome is not guaranteed for all, and high self-persistence implies that those who end up in low-paid jobs are more likely to become trapped there. Without further evidence we can only speculate about such interpretations. 
By contrast, workers who did not finish school show the highest persistence and selfpersistence of overskilling, but they only show wage losses among those who have been overskilled for three years in a row. Given the compressed wage distribution in this educational group, we cannot know whether the effect of self-persistence has been masked by a lack of wage variance within this group. Year 12 school graduates show modest wage losses which follow a similar pattern as for university graduates. Finally, VET graduates holding certificates show that their highly persistent and highly self-persistent overskilling mismatch cause no wage losses to overskilled workers. Put simply, the findings of this research are that there is an educational divide regarding the impact of overskilling mismatch. University graduates are the least likely to experience overskilling, overskilling persistence, and overskilling selfpersistence. At the same time, among all overskilled workers, it is university graduates are the ones who are the most likely to sustain self-persistent overskilling wage losses. By contrast, VET graduates show high persistence but low wage losses. In this sense it could be argued that VET is less susceptible to persistent undesirable wage losses, but this advantage would have to be seen in the context of VET wages being the lowest among all workers with post-school qualifications. 


\section{References}

Arulampalam, W \& Stewart, M 2009, 'Simplified implementation of the Heckman estimator of the dynamic probit model and a comparison with alternative estimators', Oxford Bulletin of Economics and Statistics, vol.71, pp.659-681.

Bell, D \& Blanchflower, D 2010. 'Youth unemployment: Déjà Vu?,' IZA, Discussion papers no.4705.

Heckman, J 1978, 'Simple statistical models for discrete panel data developed and applied to test the hypothesis of true state dependence against the hypothesis of spurious state dependence', annales de l'insee, vol.30-31, pp.227-269.

Mavromaras, K, McGuinness, S \& Fok, Y 2009a, 'Assessing the incidence and wage effects of overskilling in the Australian labour market', The Economic Record, vol.85, no.268, pp.60-72.

Mavromaras, K, McGuinness, S \& Fok, Y 2009b, 'The incidence and wage effects overskilling among employed VET graduates’, NCVER Monograph Series, no.03/2009, pp.1-38.

Mavromaras, K, McGuinness, S, O’Leary, N, Sloane, P \& Fok, Y 2010a, 'The problem of overskilling in Australian and Britain', The Manchester School, vol.78, no.3, pp.219-241.

Mavromaras, K, McGuinness, S, O’Leary, N, Sloane, P \& Wei, Z 2010b, 'Job mismatches and labour market outcomes: Panel evidence on Australian university graduates', IZA, Discussion paper no.5083.

Mavromaras, K, Mahuteau, S., Sloane, P \& Wei, Z 2012a, Persistence of overskilling and its effects on wage, NCVER, Adelaide.

Mavromaras, K and McGuinness, S 2012b, 'Overskilling dynamics and education pathways', Economics of Education Review, vol.31, pp.619-628.

Mavromaras, Sloane, P \& Wei, Z 2012c, 'The role of education pathways in the relationship between job mismatch, wages and job satisfaction: a panel estimation approach', Education Economics, vol.20, pp.303-321.

Mundlak, Y 1978, 'On the pooling of time series and cross section data', Econometrica, vol.46, pp.69-85.

Orme C 1997, The initial conditions problem and two-step estimation in discrete panel data models, mimeo, University of Manchester,

Watson, N \& Wooden, M 2004, 'The HILDA survey four years on', Australian Economic Review, vol.37, no.3, pp.343-349.

Wooldridge, J 2005, 'Simple solutions to the initial conditions problem in dynamic, nonlinear panel data models with unobserved heterogeneity', Journal of Applied Econometrics, vol.20, pp.39-54. 


\section{Appendix I}

\section{Definition of Variables:}

Overskilled: Dummy variable, takes the value 1 if is overskilled, zero otherwise.

Wage: Log of current hourly gross wages and salary from the main job.

Female: Dummy variable, takes the value 1 if is female, zero otherwise.

Age: Continuous variable, expressed in years.

Age Square: Continuous variable, expressed in age*age/100.

Disability: Dummy variable, takes the value 1 if an individual has disability, zero otherwise.

Married: Dummy variable, takes the value 1 if an individual is married (or de facto), zero otherwise.

Urban: Dummy variable, takes the value 1 if an individual domiciled within a major city, zero otherwise.

Father was a professional: Dummy variable, takes the value 1 if father belonged to a professional occupation, zero otherwise.

Country of birth:

Migrant (English-speaking country): Dummy variable, takes the value 1 if migrant from an English-speaking country, zero otherwise.

Migrant (non-English-speaking country): Dummy variable, takes the value 1 if migrant from a non-English-speaking country, zero otherwise.

Aboriginal or Torres Strait Islander: Dummy variable, takes the value 1 if an individual is Aboriginal or Torres Strait Islander, zero otherwise.

Australian born non-ATSI is the reference category.

Hours per week usually worked in main job: Continuous variable, expressed in hours.

Tenure in the current occupation: Continuous variable, expressed in years.

Tenure with the current employer: Continuous variable, expressed in years.

Firm size:

Less than 5 employees: Dummy variable, takes the value 1 if working in a firm which has less than 5 employees, zero otherwise.

5 to 9 employees: Dummy variable, takes the value 1 if working in a firm which has 5 to 9 employees, zero otherwise.

10 to 19 employees: Dummy variable, takes the value 1 if working in a firm which has 10 to 19 employees, zero otherwise.

20 to 49 employees: Dummy variable, takes the value 1 if working in a firm which has 20 to 49 employees, zero otherwise. 
More than 49 employees is the reference category.

Children aged between 5 and 14: Dummy variable, takes the value 1 if an individual has children between the ages of 5 and 14, zero otherwise.

Children aged under 5: Dummy variable, takes the value 1 if an individual has children aged under 5 , zero otherwise.

Per cent time spent unemployed in last financial year: Continuous variable, value of which lies between 0 and 100 .

Union member: Dummy variable, takes the value 1 if an individual is a member of a trade union, zero otherwise.

\section{Sector:}

Agriculture, forestry and fishing: Dummy variable, takes the value 1 if working in the industry of agriculture, forestry and fishing, zero otherwise.

Mining: Dummy variable, takes the value 1 if working in the industry of mining, zero otherwise.

Electricity, gas, water, and waste services: Dummy variable, takes the value 1 if working in the industry of electricity, gas, water and waste services, zero otherwise.

Construction: Dummy variable, takes the value 1 if working in the industry of construction, zero otherwise.

Wholesale trade: Dummy variable, takes the value 1 if working in the industry of wholesale trade, zero otherwise.

Retail trade: Dummy variable, takes the value 1 if working in the industry of retail trade, zero otherwise.

Accommodation and food services: Dummy variable, takes the value 1 if working in the industry of accommodation and food services, zero otherwise.

Transport, postal, and warehousing: Dummy variable, takes the value 1 if working in the industry of transport, postal, and warehousing, zero otherwise.

Information media and telecommunications: Dummy variable, takes the value 1 if working in the industry of information media and telecommunications, zero otherwise.

Financial and insurance services: Dummy variable, takes the value 1 if working in the industry of financial and insurance services, zero otherwise.

Rental, hiring, and real estate services: Dummy variable, takes the value 1 if working in the industry of rental, hiring and real estate services, zero otherwise.

Professional, scientific, and technical services: Dummy variable, takes the value 1 if working in the industry of professional, scientific and technical services, zero otherwise.

Administrative and support services: Dummy variable, takes the value 1 if working in the industry of administrative and support services, zero otherwise.

Public administration and safety: Dummy variable, takes the value 1 if working in the industry of public administration and safety, zero otherwise. 
Education and training: Dummy variable, takes the value 1 if working in the industry of education and training, zero otherwise.

Health care and social assistance: Dummy variable, takes the value 1 if working in the industry of health care and social assistance, zero otherwise.

Arts and recreation services: Dummy variable, takes the value 1 if working in the industry of arts and recreation services, zero otherwise.

Other services: Dummy variable, takes the value 1 if working in the industry of other services, zero otherwise.

Manufacturing is the reference category. 
Table A1

\begin{tabular}{|c|c|c|c|c|c|}
\hline Explanatory variable & $\begin{array}{l}\text { University } \\
\text { Graduates }\end{array}$ & Diplomas & $\begin{array}{c}\text { Certificates } \\
\text { III/IV }\end{array}$ & $\begin{array}{c}\text { Complete } \\
\text { school }\end{array}$ & $\begin{array}{c}\text { Not } \\
\text { complete } \\
\text { school } \\
\end{array}$ \\
\hline Female & 0.55 & 0.54 & 0.34 & 0.52 & 0.53 \\
\hline Age & $\begin{array}{c}39.22 \\
(10.44)\end{array}$ & $\begin{array}{c}39.95 \\
(10.47)\end{array}$ & $\begin{array}{c}38.78 \\
(11.33)\end{array}$ & $\begin{array}{c}32.79 \\
(11.85)\end{array}$ & $\begin{array}{c}40.42 \\
(12.11)\end{array}$ \\
\hline Age Square/100 & $\begin{array}{l}16.47 \\
(8.42)\end{array}$ & $\begin{array}{l}17.06 \\
(8.46)\end{array}$ & $\begin{array}{l}16.32 \\
(8.90)\end{array}$ & $\begin{array}{l}12.15 \\
(8.64)\end{array}$ & $\begin{array}{l}17.81 \\
(9.43)\end{array}$ \\
\hline Disability & 0.11 & 0.12 & 0.14 & 0.11 & 0.16 \\
\hline Married & 0.73 & 0.70 & 0.71 & 0.56 & 0.68 \\
\hline Urban & 0.93 & 0.89 & 0.85 & 0.89 & 0.84 \\
\hline Father was a professional & 0.27 & 0.17 & 0.09 & 0.17 & 0.06 \\
\hline Migrant (English speaking country) & 0.11 & 0.11 & 0.10 & 0.08 & 0.08 \\
\hline Migrant (non-English speaking country) & 0.14 & 0.10 & 0.07 & 0.11 & 0.06 \\
\hline Aboriginal or Torres Strait Islander & 0.01 & 0.01 & 0.02 & 0.02 & 0.03 \\
\hline Hours per week usually worked in main job & $\begin{array}{c}39.02 \\
(12.90)\end{array}$ & $\begin{array}{c}37.42 \\
(12.92)\end{array}$ & $\begin{array}{c}39.40 \\
(12.46)\end{array}$ & $\begin{array}{l}35.60 \\
(12.95)\end{array}$ & $\begin{array}{l}35.06 \\
(13.84)\end{array}$ \\
\hline Tenure in the current occupation & $\begin{array}{c}9.46 \\
(9.43)\end{array}$ & $\begin{array}{c}9.46 \\
(9.35)\end{array}$ & $\begin{array}{c}9.60 \\
(9.89)\end{array}$ & $\begin{array}{c}5.96 \\
(7.45)\end{array}$ & $\begin{array}{l}8.65 \\
(9.31)\end{array}$ \\
\hline Tenure with current employer & $\begin{array}{c}7.04 \\
(7.92)\end{array}$ & $\begin{array}{c}7.56 \\
(8.31)\end{array}$ & $\begin{array}{l}6.20 \\
(7.46)\end{array}$ & $\begin{array}{c}4.78 \\
(6.23)\end{array}$ & $\begin{array}{l}6.27 \\
(7.41)\end{array}$ \\
\hline Firm has less than 5 employees & 0.05 & 0.08 & 0.10 & 0.10 & 0.13 \\
\hline Firm has 5 to 9 employees & 0.07 & 0.11 & 0.14 & 0.14 & 0.15 \\
\hline Firm has 10 to 19 employees & 0.10 & 0.16 & 0.15 & 0.15 & 0.17 \\
\hline Firm has 20 to 49 employees & 0.18 & 0.20 & 0.19 & 0.18 & 0.17 \\
\hline Have children aged between 5 and 14 & 0.27 & 0.29 & 0.28 & 0.20 & 0.28 \\
\hline Have children aged under 5 & 0.14 & 0.13 & 0.13 & 0.12 & 0.09 \\
\hline $\begin{array}{l}\text { Per cent time spent unemployed in last } \\
\text { financial year }\end{array}$ & $\begin{array}{l}1.30 \\
(7.73)\end{array}$ & $\begin{array}{c}1.61 \\
(9.14)\end{array}$ & $\begin{array}{c}2.06 \\
(10.25)\end{array}$ & $\begin{array}{c}2.86 \\
(11.88)\end{array}$ & $\begin{array}{c}3.42 \\
(14.04)\end{array}$ \\
\hline Union member & 0.37 & 0.32 & 0.31 & 0.21 & 0.25 \\
\hline Agriculture, forestry and fishing & 0.01 & 0.02 & 0.02 & 0.02 & 0.04 \\
\hline Mining & 0.01 & 0.01 & 0.04 & 0.01 & 0.02 \\
\hline Electricity, gas, water and waste services & 0.01 & 0.01 & 0.02 & 0.01 & 0.01 \\
\hline Construction & 0.02 & 0.04 & 0.09 & 0.05 & 0.07 \\
\hline Wholesale trade & 0.02 & 0.03 & 0.04 & 0.04 & 0.05 \\
\hline Retail trade & 0.03 & 0.06 & 0.08 & 0.14 & 0.14 \\
\hline Accommodation and food services & 0.01 & 0.04 & 0.06 & 0.09 & 0.07 \\
\hline Transport, postal and warehousing & 0.02 & 0.04 & 0.05 & 0.06 & 0.07 \\
\hline Information media and telecommunications & 0.03 & 0.04 & 0.02 & 0.03 & 0.02 \\
\hline Financial and insurance services & 0.05 & 0.06 & 0.02 & 0.06 & 0.03 \\
\hline Rental, hiring and real estate services & 0.01 & 0.02 & 0.01 & 0.02 & 0.01 \\
\hline Prof, scientific and technical services & 0.12 & 0.07 & 0.03 & 0.06 & 0.03 \\
\hline Administrative and support services & 0.01 & 0.03 & 0.02 & 0.03 & 0.03 \\
\hline Public administration and safety & 0.11 & 0.12 & 0.08 & 0.08 & 0.05 \\
\hline Education and training & 0.27 & 0.16 & 0.04 & 0.04 & 0.05 \\
\hline Health care and social assistance & 0.18 & 0.14 & 0.14 & 0.10 & 0.11 \\
\hline Arts and recreation services & 0.01 & 0.02 & 0.01 & 0.02 & 0.01 \\
\hline
\end{tabular}




\begin{tabular}{lccccc}
\hline Other services & 0.02 & 0.03 & 0.06 & 0.03 & 0.03 \\
Observations & 13763 & 4632 & 10434 & 7672 & 11436 \\
\hline Note: Mean (standard deviation). The sample consists of all working-age paid employees from HILDA 2001-2009.
\end{tabular}

Note: Mean (standard deviation). The sample consists of all working-age paid employees from HILDA 2001-2009. 